\title{
CAUSAL MODELLING OF PARTICIPANTS REACTION IN THE MANAGEMENT TRAINING
}

\author{
Ronny Kountur \\ PPM School of Management \\ E-mail: ron@lppm.ac.id
}

\begin{abstract}
This research was intended to find out variables that affect the reaction of participants attending management courses. It was hypothesized that participants reaction are affected by variables such as instructor, course material, participation during the session, and training supporting facilities. While the participation during the session were affected by instructor and course material. The relationship between these variables is a structural form and described by a causal modeling relationship. This causal relationship was tested for its significant using path analysis technique. Data were collected using questionnaires to the 120 participants that were attending management training. The validity and reliability of this instruments had been tested. It's reliability was tested using Cronbach Alpha with a reliability of $86 \%$, which are considered as reliable. It was found out that instructor and course material affected the satisfaction of participant while attending management training, however, negative relationship was found between instructor and course material. Both of these variables, instructor and course material, were also found to affect the participation during the session. The other two variables which are participation during the session and training supporting facilities were found to have no affect on both, participants reaction and participation during the session. Two aspects of instructor that were studied, the understandability in delivering the material and the attractiveness of the presentation. While, there were also two aspects of course material that were studied, the applicability of the material and the readability of the materials.
\end{abstract}

Keywords:Model sebab -akibat, pelatihan manajemen, peserta, instruktur, materi

\section{INTRODUCTION}

Memperoleh sumber daya yang unggul tidaklah mudah karena membutuhkan waktu dan biaya yang tidak sedikit. Sumber daya manusia perlu dikembangkan dan salah satu cara mengembangkan sumber daya manusia adalah melalui pelatihan.

Sangat mungkin pelatihan gagal memberikan apa yang dibutuhkan, peserta tidak puas dengan pelatihan yang diberikan dan ini berdampak pada kemampuan peserta untuk mengaplikasikan apa yang telah dia peroleh pada pelatihan yang diberikan. Penting untuk mengetahui apa yang membuat peserta pelatihan puas dengan pelatihan yang diberikan. Oleh karena menurut Pedersen (2003), “As lecture training satisfaction increased, awareness increased."

Penelitian ini dilakukan untuk mengetahui variabel-variabel apa saja yang berhubungan dengan reaksi peserta terhadap suatu pelatihan. Dalam menganalisa hubungan ini, pendekatan model sebab akibat digunakan. Lebih spesifik lagi, penelitian ini dimaksudkan untuk menjawab pertanyaan-pertanyaan berikut ini: (1) Apakah variabel-variabel instruktur, materi, fasilitas pendukung dan partisipasi peserta berpengaruh secara signifikan terhadap tingkat kepuasan peserta pelatihan; dan (2) apakah variabel-variabel instruktur dan 
materi berpengaruh secara signifikan terhadap partisipasi peserta dalam pelatihan.

\section{Conceptual Framework}

Menurut Bangert (2006) dalam artikelnya yang berjudul Invest in Training ada tiga faktor penting dari pelatihan yang ideal yaitu (1) berdasarkan atas tujuan, (2) terkait dengan perbaikan prestasi, dan (3) pelatih yang dinamis, sebagaimana dikatakan, "Ideally, training should be goalbased, tied to improving performance and led by a dynamic instructor." Apabila ketiga faktor ini ada dalam suatu pelatihan, diharapkan reaksi peserta akan manfaat pelatihan dapat dirasakan yang seterusnya akan membuat peserta puas dengan pelatihan yang diberikan.

Leung (2003) melakukan penelitian tentang keterlibatan orang dalam melaksanakan suatu proyek. Dari hasil penelitian tersebut didapati bahwa jika suatu proyek terdapat proses penetapan tujuan, hal itu dapat memperbaiki kepuasan orang-orang yang terlibat dalam proyek tersebut. Sebagaimana dikatakan, "...goal setting process can improve the participants, satisfaction." Hasil penelitian ini konsisten dengan pendapat Bangert yang mengatakan bahwa pelatihan yang ideal yang dapat bermanfaat dan memberikan kepuasan kepada peserta adalah pelatihan yang didasarkan atas tujuan yang jelas.

Tujuan seperti apa yang diharapkan dari suatu pelatihan? Sebenarnya sudah diutarakan oleh Bangert yaitu tujuan yang terkait dengan perbaikan prestasi peserta. Tujuan pelatihan untuk memperbaiki prestasi peserta sudah harus dicakup dalam materi pelatihan sehingga faktor tujuan dan perbaikan prestasi dapat digabungkan menjadi satu aspek saja yaitu aspek materi pelatihan. Itu sebabnya ketiga aspek penting dari suatu pelatihan yang diutarakan oleh Bangert sebenarnya bisa digabungkan menjadi dua aspek utama yaitu (1) materi pelatihan, dan (2) instruktur pelatihan.

Hale (2005) dalam artikelnya yang berjugul "Don't Train; Motivate" mengungkapkan bahwa perlu ada keseimbangan antara membangun motivasi peserta dan mendorong pemahaman atas materi yang diberikan. Instruktur pelatihanlah yang berperan dalam membangun motivasi peserta. Peserta yang berpartisipasi dalam memberikan pendapat, bertanya, dan aktif dalam kegiatan pelatihan ternyata berhubungan dengan tingkat motivasinya. Dan peserta yang terlibat aktif dalam proses pelatihan akan mempunyai keinginan untuk mencapai tujuan yang positif, sebagaimana diungkapkan Hale (2005) bahwa "By feeling empowered to control the content and direction of the training course, the trainees will take more ownership of the material and have a vested interest in achieving a positive outcome." Disini nampak bahwa instruktur berperan dalam menimbulkan niat bagi peserta untuk turut berpartisipasi.

Peran instruktur bukan saja untuk mendorong peserta berpartisipasi tetapi juga dalam membuat peserta puas atas pelatihan yang diberikan. Ada dua aspek dari instruktur pelatihan yang dapat membuat peserta pelatihan puas dengan instruktur yaitu (1) cara penyampaian, dan (2) metode yang digunakan. Dari hasil studi ditemukan kalau metode pengajaran yang menggunakan grafik dan visual aids dapat membuat materi yang diberikan mudah diingat (Anonymous, 2006). Lain lagi dengan penelitian yang dilakukan oleh Pedersen (2003) yang mendapati bahwa tingkat pemahaman peserta dalam suatu pelatihan lebih tinggi jika menggunakan metode computer-based dibandingkan dengan metode lecturing. Dengan kata lain, ada beberapa metode yang instruktur pelatihan dapat gunakan dan metode-metode ini berhubungan dengan daya ingat dan pemahaman peserta. Semakin 
paham peserta, semakin puas dia dengan pelatihan yang diikuti.

Pissarra, Jesuino, dan Jorge (2005) melakukan penelitian tentang efektifitas penggunaan alat-alat bantu dalam proses brainstorming apakah dapat menfasilitasi munculnya ide-ide yang produktif. Didapati bahwa karakteristik alat mengganggu mekanisme kognitif (cognitive) pada proses brainstorming. Selanjutnya, didapati bahwa ada pengaruh antara alat bantu yang digunakan dan kepuasan peserta. Alat bantu tertentu memberikan kepuasan pada peserta.

Kepuasan peserta dalam mengikuti pelatihan sangat penting mengingat "... participants' satisfaction level... significantly affect how participants feel about their investments." (Anonymous, 2004). Selanjutnya, "trainees who had positive reactions to training (satisfy) were more likely to learn the material, and trainees with higher levels of knowledge retention were more likely to apply the material in the work environment." (Leach \& Liu, 2003).

Model Sebab-Akibat (causal modeling) atau kadang-kadang dikenal juga dengan isilah model persamaan struktural adalah suatu cara yang dapat digunakan untuk menjelaskan hubungan antara variabel yang sangat rumit. Hubungan dikatakan rumit oleh karena memungkinkan terdapat beberapa variabel independen yang sekaligus dihubungkan dengan beberapa variabel dependen. Ini yang membuat hubungan tersebut disebut rumit. Ferdinand (2002) mengungkapkan, "Model Persamaan Struktural, Structural Equation Model (SEM) adalah sekumpulan teknik-teknik statistikal yang memungkinkan pengujian sebuah rangkaian hubungan yang relatif "rumit", secara simultan. Hubungan yang rumit itu dapat dibangun antara satu atau beberapa variabel dependen dengan satu atau beberapa variabel independen. Masing-masing variabel dependen dan independen dapat berbentuk faktor (atau konstruk, yang dibangun dari beberapa variabel indikator)."

Model Sebab-Akibat dibentuk berdasarkan teori. Hubungan sebab akibat dari variabel-variabel yang terlibat didasarkan atas teori yang kuat sebagai mana dikatakan Asher (1983), "The use of causal modeling is to begin with a model results from some theoretical or substantive reasoning about the linkages between the variables of interest."

Variabel-variabel yang terlibat didalam model sebab-akibat (casual modeling) ini dapat berupa variabel exogenous atau variabel endogenous. Sebagaimana dikatakan Asher (1983) exogenous variable adalah variabel yang tidak dipengaruhi oleh variabel lainnya. Exogenous variable juga dikenal sebagai variabel independen. Sedangkan endogenous variable adalah variabel yang dipengaruhi oleh variabel lainnya yang juga dikenal sebagai variabel dependen. Untuk mengetahui besarnya pengaruh antara satu variabel dengan variabel lainnya didalam model sebabakibat, dua metode dapat digunakan (Asher, 1983) yaitu, (1) Instrument variabel method, dan (2) Ordinary regression technique.

Sebagaimana dikatakan oleh Asher (1983), ada dua manfaat dari model sebabakibat ini. Pertama, "it enable to measure the direct and indirect effects that one variable has on other." Dan yang kedua, "enable to decompose the correlation between any two variables into a sum of simple and compound paths." Yang dimaksud dengan "simple" path disini adalah pengaruh yang langsung, sedangkan "compound" path adalah pengaruh yang tidak langsung. Total pengaruh (atau total effect) adalah jumlah antara pengaruh langsung dan pengaruh tidak langsung. Ada beberapa variabel yang menentukan kepuasan peserta ketika mengikuti pelatihan. Variabel-variabel tersebut diantaranya instruktur pelatihan, 
partisipasi peserta, materi pelatihan, dan fasilitas penunjang pelatihan. Juga diketahui kalau instruktur dan materi pelatihan mempengaruhi partisipasi peserta ketika mengikuti pelatihan. Hubungan antara variabel ini dapat digambarkan sebagai model sebab-akibat dari reaksi peserta pada pelatihan manajemen yang digambarkan pada Gambar 1.

Berdasarkan kerangka konsep ini maka hipotesa penelitian dirumuskan sebagai berikut, kepuasan peserta mengikuti pelatihan manajemen $(\mathrm{Y})$ dipengaruhi oleh variabel-variabel seperti instruktur yang memberikan pelatihan $\left(\mathrm{X}_{1}\right)$, materi pelatihan $\left(\mathrm{X}_{2}\right)$, partisipasi peserta dalam mengikuti pelatihan $\left(\mathrm{X}_{3}\right)$, dan fasilitas penunjang pelatihan $\left(\mathrm{X}_{4}\right)$. Sementara partisipasi peserta dalam mengikuti pelatihan $\left(\mathrm{X}_{2}\right)$ dipengaruhi oleh instruktur yang memberikan pelatihan $\left(\mathrm{X}_{1}\right)$, dan materi pelatihan $\left(\mathrm{X}_{2}\right)$.

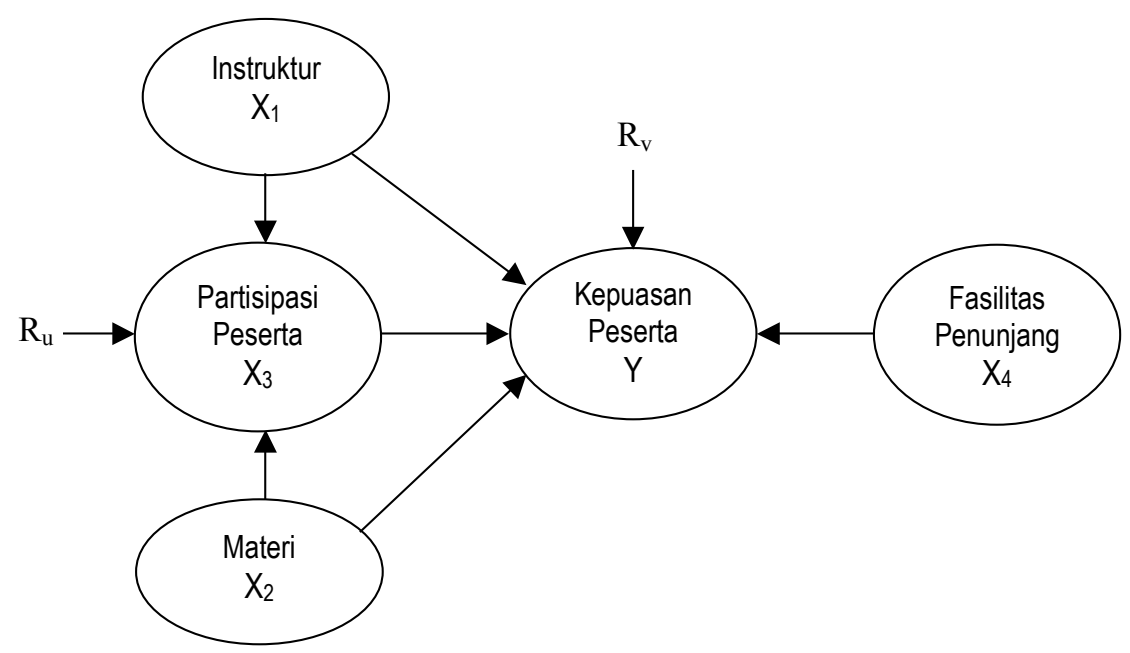

$\mathrm{R}_{\mathrm{u}}$ dan $\mathrm{R}_{\mathrm{v}}$ adalah nilai residual dari endogenous variable masing-masing partisipasi peserta $\left(\mathrm{X}_{3}\right)$ dan kepuasan peserta $(\mathrm{Y})$.

Gambar 1: Model Sebab-Akibat Dari Reaksi Peserta Pada Pelatihan Manajemen 


\section{METHODOLOGY}

Penelitian ini menggunakan metode path analysis. Path analysis adalah suatu metode dimana data dikumpulkan untuk melihat apakah ada hubungan sebab-akibat yang signifikan antara variabel yang saling berpengaruh. Itu sebabnya metode ini dikenal juga dengan istilah model sebabakibat atau causal modeling.

Metode penelitian ini dimulai dengan mengumpulkan teori-teori yang berhubungan yang dapat menjelaskan hubungan sebab-akibat antara variabel. Itu sebabnya hubungan antara variabel dijelaskan dengan suatu kerangka. Hubungan tersebut kemudian dikonfirmasi dengan mengumpulkan data pada saat yang bersamaan.

Pemilihan sampel dilakukan secara random dan terkumpul 120 kuesioner untuk dianalisa. Data diambil dari peserta yang mengikuti pelatihan pada tahun 2007. Kuesioner telah diuji reliabilitasnya dengan Cronbach Alpha dan diperoleh angka reliabilitas $86 \%$.

Langkah-langkah yang dilakukan dalam analisa data adalah sebagai berikut: (1) menyusun model sebab-akibat, (2) menguji hipotesa dengan menggunakan regresi berganda pada tingkat keyakinan 95\%, dan (3) menentukan total effect. Sesuai dengan Wright rules, total effect adalah jumlah dari direct effect dan indirect effect (Asher, 1983). Pada model sebab-akibat, sangat memungkinkan suatu variabel mempengaruhi variabel lainnya secara langsung (direct effect) dan secara tidak langsung (indirect effect). Dengan demikian, pengaruh secara keseluruhan (total effect) dari suatu variabel terhadap variabel lainnya adalah jumlah dari pengaruh langsung dan pengaruh tidak langsung variabel tersebut.

ANALYSIS AND INTERPRETATION Kepuasan Peserta Mengikuti Pelatihan Diduga kalau Kepuasan Peserta mengikuti pelatihan manajemen (Y) yang merupakan exogeneous variable dipengaruhi oleh Instruktur $\left(\mathrm{X}_{1}\right)$, Materi $\left(\mathrm{X}_{2}\right)$, Partisipasi Peserta $\left(\mathrm{X}_{3}\right)$, dan Fasilitas Penunjang $\left(\mathrm{X}_{4}\right)$ yang merupakan endogenelus variables.

Untuk menguji apakah ada pengaruh antara endogenous variable terhadap exogeneous variable, ada dua metode yang dapat digunakan (Asher, 1983) yaitu: (2) instrument variable method, atau (2) ordinary regression technique.

Karena ada dua pilihan maka perlu ditentukan mana yang akan digunakan. Disini yang dipilih adalah ordinary regression technique. Metode ini dipilih mengingat cara perhitungan regresi lebih mudah dilakukan karena tersedia pada beberapa software statistik. Lain halnya dengan metode instrument variable yang belum banyak tersedia pada softwaresoftware statistik. Software yang akan digunakan dalam menghitung regresi disini adalah SPSS (Statistical Program for Social Science).

Model regresi dari pengaruh instruktur, materi, partisipasi peserta, dan fasilitas penunjang terhadap kepuasan peserta yang mengikuti pelatihan manajemen adalah sebagai berikut:

$$
Y=\rho_{0}+\rho_{1} X_{1}+\rho_{2} X_{2}+\rho_{3} X_{3}+\rho_{4} X_{4}
$$

Dimana:

$$
\begin{array}{ll}
Y & =\underset{ }{\text { kepuasan }} \text { pelatihan } \\
\rho_{0} & =\text { konstanta } \\
\rho_{1,2,3,4} & =\text { koefisien } X_{1}, X_{2}, X_{3}, \text { dan } X_{4} \\
X_{1} & =\text { instruktur } \\
X_{2} & =\text { materi } \\
X_{3} & =\text { partisipasi peserta } \\
X_{4} & =\text { fasilitas penunjang }
\end{array}
$$

Hipotesa penelitian:

$\left(\mathrm{H}_{1}\right): \rho_{l}, \rho_{2}, \rho_{3}$, dan $\rho_{4} \neq 0$

Sedangkan hipotesa nul:

$\left(\mathrm{H}_{0}\right): \rho_{l}, \rho_{2}, \rho_{3}$, dan $\rho_{4}=0$ 
Data dari 120 responden yang diambil dari mereka yang telah mengikuti pelatihan manajemen dianalisa menggunakan teknik regresi. Hasil pengolahan data regresi (ordinary regression) dengan SPSS dapat ditunjukkan pada Tabel 1.

Dari hasil pengolahan data ini dapat diketahui kalau model regresinya signifikan sehingga dapat dilanjutkan ke proses selanjutnya. Sesuai dengan hasil pengujian model regressi dengan ANOVA didapati kalau nilai signifikansinya (sig.) sama dengan 0,000 jauh dibawah nilai signfikan (significant leve) yang ditetapkan sebesar 0,05 itu sebabnya dapat dilanjutkan keproses selanjutnya yang berarti bahwa endogeneous variables dapat digunakan untuk memprediksi exogeneous variable.

Pada proses selanjutnya didapati kalau dua dari empat endogeneous variables tidak signifikan yaitu variabel $\mathrm{X}_{3}$ dan $\mathrm{X}_{4}$. Hanya variabel $X_{1}$ dan $X_{2}$ yang signifikan dengan nilai sig. 0,000 jauh dibawah nilai signifikansi yang disyaratkan sebesar 0,005. Nilai absolut signifikan dari variabel $\mathrm{X}_{3}$ dan $\mathrm{X}_{4}$ lebih besar dari nilai signifikansi yang disyaratkan yaitu 0,0661 dan 0,0195 (nilai abosulut dari -0,0195).

Tabel 1: Hasil Pengolahan Data Ordinary Regression Dengan Spss Untuk Model Kepuasan Peserta

\begin{tabular}{rlrrrrr}
\multicolumn{7}{c}{ ANOVA(b) } \\
\hline \multirow{2}{*}{ Model } & & $\begin{array}{c}\text { Sum of } \\
\text { Squares }\end{array}$ & df & $\begin{array}{c}\text { Mean } \\
\text { Square }\end{array}$ & F & Sig. \\
\hline 1 & Regression & 17,992 & 4 & 4,498 & 26,391 &, $000(\mathrm{a})$ \\
& Residual & 19,600 & 115 &, 170 & & \\
& Total & 37,592 & 119 & & & \\
& & & & &
\end{tabular}

a Predictors: (Constant), X4, X1, X3, X2

b Dependent Variable: Y

Coefficients(a)

\begin{tabular}{|c|c|c|c|c|c|c|c|c|}
\hline \multirow[t]{2}{*}{ Mode } & & \multicolumn{2}{|c|}{$\begin{array}{l}\text { Unstandardized } \\
\text { Coefficients }\end{array}$} & \multirow{2}{*}{$\begin{array}{c}\begin{array}{c}\text { Standardized } \\
\text { Coefficients }\end{array} \\
\text { Beta }\end{array}$} & \multirow[t]{2}{*}{$t$} & \multirow[t]{2}{*}{ Sig. } & \multicolumn{2}{|c|}{ Collinearity Statistics } \\
\hline & & B & $\begin{array}{l}\text { Std. } \\
\text { Error }\end{array}$ & & & & Tolerance & VIF \\
\hline \multirow[t]{5}{*}{1} & (Constant) & 878 & ,342 & & 2,567 & ,012, & & \\
\hline & $\mathrm{X} 1$ & 374 & ,092 & 355, & 4,050 &, 000 &, 590 & 1,695 \\
\hline & $\mathrm{X} 2$ & ,374 & 097, & ,373 & 3,873 & ,000 & ,488 & 2,049 \\
\hline & X3 & ,067 & 057, & 094, & 1,178 & 241, & ,711 & 1,407 \\
\hline & $X 4$ &,- 017 & 084, &,- 018 &,- 201 & 841, & ,596 & 1,678 \\
\hline
\end{tabular}

a Dependent Variable: Y 
Karena ada variabel yang tidak signifikan, pengolahan data diulang kembali dengan hanya memasukkan variabel-variabel yang signifikan saja. Tabel 2 menunjukkan hasil pengolahan data setelah variabel-variabel yang tidak signifikan dikeluarkan.

Setelah kedua endogeneous variables yang tidak signifikan dikeluarkan dari model, didapati bahwa model yang baru tetap signifikan dengan nilai uji model regressi ANOVA menunjukkan nilai 0,000 sangat jauh dibawah nilai signifikansi yang ditetapkan sebesar 0,05. Ini berarti bahwa endogeneous variables dapat digunakan untuk memprediksi exogeneous variable.

Tabel 2: Hasil Pengolahan Data Ordinary Regression Dengan Spss Setelah Variabel Yang Tidak Signifikan Dikeluarkan

\begin{tabular}{|c|c|c|c|c|c|c|}
\hline \multicolumn{7}{|c|}{ ANOVA(b) } \\
\hline Model & & $\begin{array}{l}\text { Sum of } \\
\text { Squares }\end{array}$ & $d f$ & $\begin{array}{l}\text { Mean } \\
\text { Square }\end{array}$ & $\mathrm{F}$ & Sig. \\
\hline \multirow[t]{3}{*}{1} & Regression & 17,747 & 2 & 8,874 & 52,318 & ,000(a) \\
\hline & Residual & 19,844 & 117 & ,170 & & \\
\hline & Total & 37,592 & 119 & & & \\
\hline
\end{tabular}

a Predictors: (Constant), X2, X1

b Dependent Variable: Y

Model Summary(b)

\begin{tabular}{ccccc}
\hline Model & $\mathrm{R}$ & R Square & Adjusted R Square & $\begin{array}{c}\text { Std. Error of the } \\
\text { Estimate }\end{array}$ \\
\hline 1 &, $687(\mathrm{a})$ &, 472 &, 463 &, 41184 \\
\hline
\end{tabular}

a Predictors: (Constant), X2, X1

b Dependent Variable: Y

\begin{tabular}{|c|c|c|c|c|c|c|c|c|}
\hline \multirow[t]{2}{*}{ Model } & & \multicolumn{2}{|c|}{$\begin{array}{c}\text { Unstandardized } \\
\text { Coefficients }\end{array}$} & \multirow{2}{*}{$\begin{array}{c}\begin{array}{c}\text { Standardized } \\
\text { Coefficients }\end{array} \\
\text { Beta }\end{array}$} & \multirow[t]{2}{*}{$t$} & \multirow[t]{2}{*}{ Sig. } & \multicolumn{2}{|c|}{ Collinearity Statistics } \\
\hline & & B & Std. Error & & & & Tolerance & VIF \\
\hline \multirow[t]{3}{*}{1} & (Constant) & ,919 & ,316 & & 2,911 &, 004 & & \\
\hline & $\mathrm{X} 1$ & ,398 & ,090 & ,378, & 4,421 &, 000 & ,619 & 1,616 \\
\hline & $\mathrm{X} 2$ & 387, & 086, & 387, & 4,526 &, 000 & ,619 & 1,616 \\
\hline
\end{tabular}

Coefficients(a)

a Dependent Variable: Y 
Dari hasil perhitungan Adjusted $\mathrm{R}$ Square $\left(\mathrm{R}^{2}\right)$ didapati nilai 0,463 yang berarti bahwa $46,3 \%$ variance dari exogeneous variable dapat dijelaskan oleh endegeneous variable. Dengan kata lain 46,3\% perubahan pada kepuasan peserta mengikuti pelatihan ditentukan oleh instruktur dan materi.

Variabel $\mathrm{X}_{1}$ yaitu INSTRUKTUR mempunyai koeficien 0,398 sedangkan varabel $\mathrm{X}_{2}$ yaitu MATERI mempunyai koefisien 0,387 dengan konstanta sebesar 0,919 . Kedua variabel ini signifikan oleh karena nilai sig. yang lebih kecil dari 0,05 yaitu masing-masing 0,000 .

Model regresi dari KEPUASAN PESERTA mengikuti pelatihan ini dapat ditunjukkan dengan persamaan sebagai berikut:

$$
\mathrm{Y}=0,919+0,398 \mathrm{X}_{1}+0,387 \mathrm{X}_{2}
$$

Dimana:

$\mathrm{Y}=$ Kepuasan Peserta mengikuti pelatihan manajemen

$\mathrm{X}_{1}=$ Instruktur yang memberikan pelatihan $\mathrm{X}_{2}=$ Materi pelatihan

Menurut Black (1997), beberapa asumsi yang seharusnya dipenuhi oleh model regresi diantaranya (1) data terdistribusi secara normal, (2) tidak terdapat multicollinearity atau error term-nya independen, (3) modelnya linear, dan (4) tidak terdapat heteroschedasticity.
Sesuai dengan central limit theorem, "Jika suatu populasi yang memiliki rata-rata $(\mu)$ dan deviasi standar $(\sigma)$ dibagi rata seluruhnya ke dalam beberapa sampel, dimana anggota dari sampel-sampel tersebut dipilih secara random, rata-rata (mean) dari sampel akan terdistribusi secara normal untuk sampel yang memiliki anggota yang lebih besar atau sama dengan $30(n \geq 30)$ tidak perduli apakah distribusi dari populasi tersebut normal atau tidak." (Kountur, 2005). Oleh karena data dipilih secara random dan lebih besar dari 30 maka asumsi pertama bahwa distribusi data normal sudah dapat dipenuhi.

Dari TABEL 2 Didapati kalau nilai tollerance dari collinearity statistics untuk variabel $X_{1}$ dan $X_{2}$ masing-masing 0,619. Dari nilai ini dicurigai terdapat multicollinearity. Tabel 3 Coefficient Correlations dari hasil pengolahan data SPSS menunjukkan nilai korelasi $X_{1}$ dan $X_{2}$ sebesar $-0,617$. Sesuai dengan Santoso (2000) nilai korelasi diatas 0,5 dianggap memiliki masalah multicollinearity. Ini berarti bahwa variabel $\mathrm{X}_{1}$ dan $\mathrm{X}_{2}$ saling berkorelasi. Menggunakan salah satu variabel saja sudah dapat digunakan untuk memprediksi exogeneous variable. Walaupun demikian, kedua variabel ini tetap dianggap sebagai penentu kepuasan peserta mengikuti pelatihan pada model sebab akibat dengan menggambarkan hubungannya.

Tabel 3: Coefficient Correlations

\begin{tabular}{|c|c|c|c|c|}
\hline Model & & & $X 2$ & $\mathrm{X} 1$ \\
\hline \multirow[t]{4}{*}{1} & Correlations & $\mathrm{X} 2$ & 1,000 &,- 617 \\
\hline & & $\mathrm{X} 1$ &,- 617 & 1,000 \\
\hline & Covariances & $\mathrm{X} 2$ &, 007 &,- 005 \\
\hline & & $X 1$ &,- 005 & ,008 \\
\hline
\end{tabular}

a Dependent Variable: $Y$ 
Dengan melihat distribusi residual (residual plot) seperti yang dapat dilihat pada Gambar 2 didapati sebaran yang teratur dengan membuat suatu diagonal. Sebaran seperti ini menunjukkan adanya dependency dari error. Hal ini terjadi oleh karena adanya multicolinearity. Namun sebaran seperti ini juga berarti bahwa model bebas dari heteroscedasticity.

\section{Partisipasi Peserta Dalam Pelatihan}

Diduga kalau peserta aktif berpartisipasi (Partisipasi Peserta) dalam pelatihan manajemen $\left(\mathrm{X}_{3}\right)$ yang merupakan exogeneous variable dipengaruhi oleh Instruktur $\left(\mathrm{X}_{1}\right)$ dan Materi $\left(\mathrm{X}_{2}\right)$ yang merupakan endogeneous variables. Model regresi dari pengaruh instruktur dan materi terhadap partisipasi peserta dalam mengikuti pelatihan manajemen adalah sebagai berikut:

$$
X_{3}=\rho_{0}+\rho_{5} X_{1}+\rho_{6} X_{2}
$$

Dimana:

$X_{3}=$ partisipasi peserta dalam mengikuti pelatihan

$\rho_{0} \quad=$ intercept

$\rho_{5,6}=$ koeficien $X_{1}, X_{2}$

$X_{I}=$ instruktur
$X_{2}=$ materi

Hipotesa penelitian $\left(\mathrm{H}_{1}\right): \rho_{5}$ dan $\rho_{6} \neq 0$

Sedangkan hipotesa nul $\left(\mathrm{H}_{0}\right): \rho_{5}$ dan $\rho_{6}=0$

Model regresi ini diuji dan sesuai dengan hasil pengolahan data SPSS seperti yang dapat dilihat pada Tabel 4 diketahui kalau model regresi ini signifikan dengan nilai sig. pada uji ANOVA yang sama dengan nol jauh dibawah tingkat signifikansi yang disyaratkan 0,05 . Namun, adjusted $R$ square-nya kecil yaitu hanya 0,181 . Dengan kata lain hanya $18,1 \%$ perubahan pada partisipasi peserta $\left(\mathrm{X}_{3}\right)$ dalam pelatihan ditentukan oleh instruktur $\left(\mathrm{X}_{1}\right)$ dan materi $\left(\mathrm{X}_{2}\right)$.

Variabel instruktur $\left(\mathrm{X}_{1}\right)$ dan materi $\left(\mathrm{X}_{2}\right)$ signifikan mempengaruhi variabel partisipasi peserta $\left(\mathrm{X}_{3}\right)$ dalam pelatihan yang ditunjukkan dengan nilai sig. masing-masing 0.020 dan 0,024 lebih kecil dari nilai signifikan yang disyaratkan 0,05 seperti yang dapat dilihat pada Tabel 4, namun konstanta-nya tidak signifikan, dengan nilai sig. 0,064 yang lebih besar dari nilai signifikan yang disyaratkan 0,05 . Koefisien dari masing-masing endogeneous variabel ini adalah 0,365 dan 0,337 .

\section{Scatterplot}

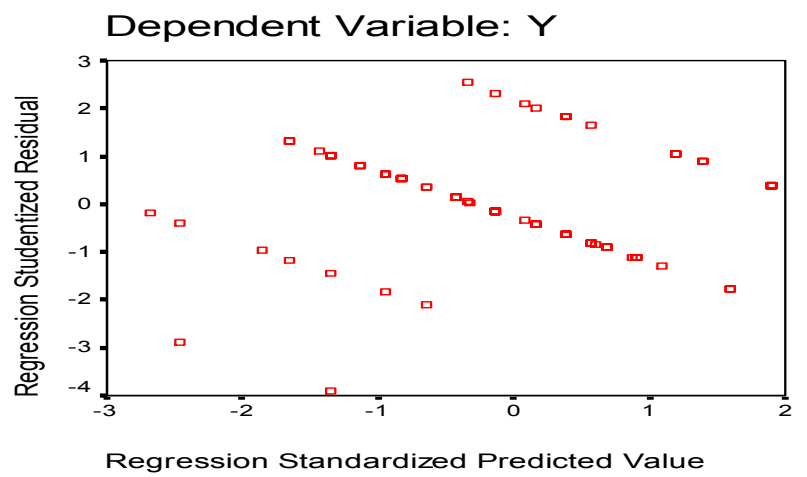

Gambar 2: Residual Plot 
Tabel 4: Hasil Pengolahan Data Ordinary Regression Dengan Spss Untuk Model Partisipasi Peserta

\begin{tabular}{llrrrrr}
\hline Model & & $\begin{array}{c}\text { Sum of } \\
\text { Squares }\end{array}$ & df & \multicolumn{1}{c}{$\begin{array}{c}\text { Mean } \\
\text { Square }\end{array}$} & F & Sig. \\
\hline & Regression & 14,220 & 2 & 7,110 & 14,122 & ,000(a) \\
Residual & 58,905 & 117 &, 503 & & \\
& Total & 73,125 & 119 & & & \\
\hline
\end{tabular}

a Predictors: (Constant), X2, X1

ANOVA(b)

b Dependent Variable: X3

Model Summary(b)

\begin{tabular}{llrrrr}
\hline Model & $\mathrm{R}$ & R Square & $\begin{array}{c}\text { Adjusted R } \\
\text { Square }\end{array}$ & $\begin{array}{c}\text { Std. Error of the } \\
\text { Estimate }\end{array}$ \\
\hline 1 &, $441(\mathrm{a})$ &, 194 &, 181 &, 70955 \\
\hline
\end{tabular}

a Predictors: (Constant), X2, X1

b Dependent Variable: X3

\section{Coefficients(a)}

\begin{tabular}{|c|c|c|c|c|c|c|c|c|}
\hline \multirow[t]{2}{*}{ Model } & & \multicolumn{2}{|c|}{$\begin{array}{l}\text { Unstandardized } \\
\text { Coefficients }\end{array}$} & $\begin{array}{c}\text { Standardized } \\
\text { Coefficients }\end{array}$ & \multirow[t]{2}{*}{$t$} & \multirow[t]{2}{*}{ Sig. } & \multicolumn{2}{|c|}{$\begin{array}{l}\text { Collinearity } \\
\text { Statistics }\end{array}$} \\
\hline & & B & $\begin{array}{l}\text { Std. } \\
\text { Error }\end{array}$ & Beta & & & Tolerance & VIF \\
\hline \multirow[t]{3}{*}{1} & (Constant) & 1,017 &, 544 & & 1,869 & ,064 & & \\
\hline & $\mathrm{X} 1$ &, 365 & 155 & 249 & 2,359 & ,020 & 619 & 1,616 \\
\hline & $\mathrm{X} 2$ & ,337 & 147 & 242 & 2,290 & ,024 & 619 & 1,616 \\
\hline
\end{tabular}

a Dependent Variable: X3

Model Partisipasi Peserta dalam mengikuti pelatihan manajemen dapat dirumuskan sebagai berikut:

$$
X_{3}=0,365 X_{1}+0,337 X_{2}
$$

Dimana:

$X_{3}=$ partisipasi peserta dalam mengikuti pelatihan

$X_{I}=$ instruktur yang memberikan pelatihan

$X_{2}=$ materi yang digunakan

Sama seperti pada model kepuasan peserta, model partisipasi peserta ini juga memenuhi asumsi normalitas dan tidak terdapat heteroschedasticity namun terdapat multicollinearity antara variabel $\mathrm{X}_{1}$ dan $\mathrm{X}_{2}$.

\section{Model Sebab-Akibat Reaksi Peserta}

Reaksi peserta apakah puas atau tidak ketika mengikuti pelatihan manajemen ditentukan oleh faktor instruktur dan materi, sedangkan terdapat korelasi antara instruktur dan materi. Demikian pula dengan keinginan peserta untuk berpartisipasi baik dalam bertanya atau memberikan pendapat/komentar pada saat mengikuti pelatihan manajemen 
ditentukan oleh faktor instruktur dan/atau materi pelatihannya. Hubungan sebab akibat ini dapat digambarkan sebagaimana yang dapat dilihat pada Gambar 3.

Kepuasan peserta mengikuti pelatihan sangat ditentukan oleh instruktur. Hal ini konsisten dengan apa yang dikatakan Bangert (2006) "Training should be ... led by a dynamic instructor." Selain instruktur, kepuasan peserta mengikuti pelatihan juga ditentukan oleh materi pelatihan yang diberikan. Sedangkan faktor-faktor lain seperti apakah peserta aktif terlibat dalam bertanya atau memberikan komentar tidak menentukan kepuasan peserta mengikuti pelatihan. Demikian pula dengan faktor penunjang pelatihan seperti ruangan dan peralatan pelatihan tidak menentukan.

Ada dua aspek dari instruktur yang dilihat dalam penelitian ini yaitu aspek kejelasan menyampaikan materi, dan aspek ketertarikan metode pengajaran yang digunakan. Oleh karena instruktur secara signifikan mempengaruhi kepuasan peserta maka dua aspek yang sangat penting dari instruktur yang dapat menentukan kepuasan peserta mengikuti pelatihan adalah (1) menyampaikan materi dengan jelas, dan (2) menggunakan metode pengajaran yang menarik. Semakin jelas materi yang diberikan, dan semakin menarik metode pengajaran yang diberikan, semakin puas peserta mengikuti suatu pelatihan manajemen.

Selain itu, kedua aspek instruktur ini dapat pula menentukan partisipasi peserta dalam pelatihan. Semakin jelas materi yang disampaikan instruktur dan semakin menarik instruktur tersebut akan mendorong peserta untuk berpartisipasi dalam bertanya, memberikan komentar dan mengerjakan tugas-tugas yang diberikan instruktur secara aktif.

Sebagaimana beberapa studi menunjukkan bahwa instruktur yang menarik adalah apabila instruktur tersebut dinamis (Bangert, 2006), yaitu dalam penyampaian materi dapat menyesuaikan dengan kebutuhan peserta sehingga tidak nampak kaku. Selanjutnya, supaya menarik, instruktur juga harus dapat membangun motivasi peserta (Hale, 2005).

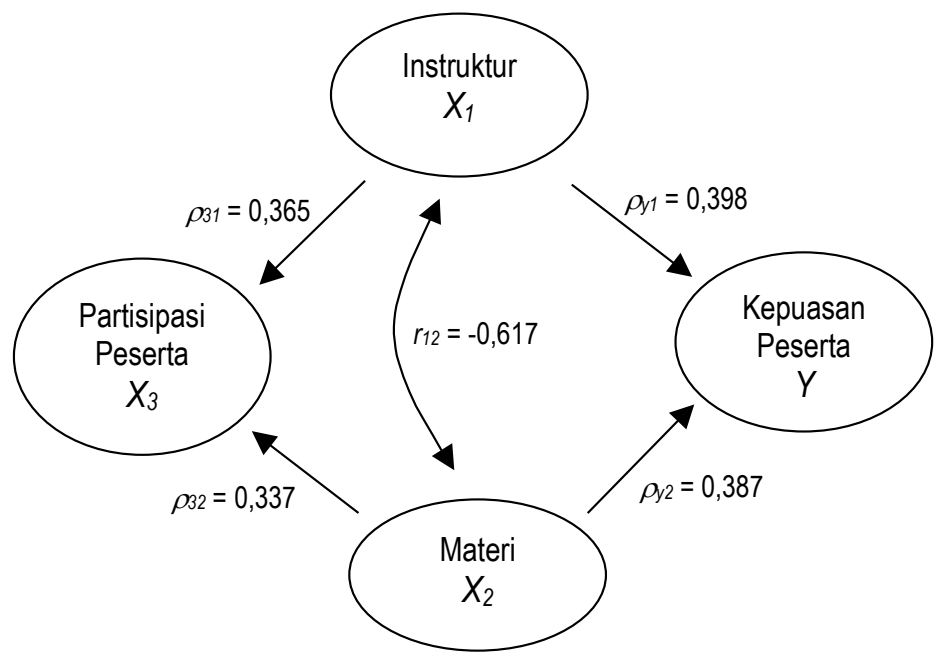

Gambar 3: Model Reaksi Peserta Pada Pelatihan Manajemen 
Menyangkut materi pelatihan, ada dua aspek yang dilihat yaitu aspek kesesuaian subyek dengan kebutuhan, dan bahan bacaan yang membantu proses belajar. Oleh karena ada hubungan yang signifikan antara materi pelatihan dan kepuasan peserta mengikuti pelatihan, itu berarti bahwa semakin sesuai subyek dengan kebutuhan peserta, semakin puas peserta mengikuti pelatihan. Demikian pula dengan bahan bacaan. Semakin banyak bahan bacaan membantu proses belajar semakin puas peserta. Hal yang sama berlaku pada partisipasi peserta selama mengikuti pelatihan. Semakin sesuai subyek dengan kebutuhan semakin terlibat peserta berpartisipasi dalam pelatihan, dan semakin membantu bahan bacaan semakin terlibat peserta berpartisipasi.

\section{CONCLUSION}

Dari hasil analisa data, dapat disimpulan, (1) Data mendukung hipotesa yang mengatakan bahwa Instruktur dan Materi mempengaruhi tingkat Kepuasan Peserta mengikuti pelatihan dan keterlibatan peserta berpartisipasi selama mengikuti pelatihan. Instruktur dan materi mempunyai pengaruh yang signifikan terhadap kepuasan peserta mengikuti pelatihan-pelatihan manajemen. Itu sebabnya sangat penting untuk memilih instruktur-instruktur yang dapat menyampaikan materi dengan jelas dan menarik. Instruktur perlu mendapat pelatihan-pelatihan tentang cara menyampaikan materi dengan jelas dan menarik.

(2) Data tidak mendukung hipotesa yang mengatakan kalau partisipasi peserta dalam mengikuti pelatihan dan fasilitas pendukung pelatihan mempengaruhi kepuasan peserta mengikuti pelatihan. Tidak ada pengaruh yang signifikan antara fasilitas pendukung dan kepuasan mengikuti pelatihan. Demikian pula dengan partisipasi peserta dan kepuasan mengikuti pelatihan tidak berpengaruh.

(3) Bahwa instruktur yang menyampaikan pelatihan dengan jelas dan menarik tidak menjamin materinya sesuai dengan kebutuhan peserta, bahkan terdapat hubungan yang negatif.

\section{REFERENCES}

Anonymous. (2006). "Martha McGinnis". $T+D$, vol. 60, p. 80.

Anonymous. (2004). "Plan Communication and Education Affects Investment Satisfaction". Pension Benefits, vol. 13, p. 10.

Asher, Helbert B. (1983). Causal Modeling, $2^{\text {nd }}$ ed. Newbury Park: Sage Publications.

Bangert, Michelle. (2006). "Invest in Training”. Quality, vol. 45.

Black, Ken. (1997). Business Statistics: Contemporary Decision Making, $2^{\text {nd }}$ ed. Minneapolis: West Publishing Company.

Ferdinand, Augusty. (2002). Structural Equation Modeling dalam Penelitian Manajemen. Semarang: BP Undip.

Hale, Ryan. (2005). “Don't Train; Motivate”. Quality, vol. 44, p. 48.

Kountur, Ronny. (2005). Statistik Praktis: Pengolahan Data untuk Penyusunan Skripsi dan Tesis. Jakarta: Penerbit PPM. 
Leach, Mark P. \& Liau, Annie H. (2003). "Investigating Interrelationships Among Sales Training Evaluation Methods". Journal of Personal Selling \& Sales Management, vol. 23, p. 327

Leung, Mei-Yung \& Liau, Anita. (2003). "Analysis of Value and Project Goal Specificity in Value Management". Construction Management \& Economics, vol. 21, p. 11.

Pedersen, Alice. (2003). "Compliance Training - How Effective is it, Really?". Journal of Health Care Compliance, vol. 2, p. 34.

Pissarra, Joao, dan Jorge. (2005). "Compliance Training-How Effective is it, Really?." Journal of Health Care Compliance, vol. 5, p. 275.

Santoso, Singgih. (2000). Buku Latihan SPSS Statistik Parametrik. Jakarta: Elex Media Komputindo. 